\title{
KEEFEKTIFAN LITERASI DIGITAL UNTUK MENINGKATKAN KEMAMPUAN BERPIKIR LOGIS DAN MENGUNGKAPKAN BAHASA ANAK
}

\author{
Umaiyah Habibah $^{1}$, Rachma Hasibuan ${ }^{2}$, Sri Setyowati ${ }^{3}$ \\ Program Pascasarjana, Universitas Negeri Surabaya ${ }^{1,2,3}$ \\ Email: ${ }^{\text {umaiyah3@gmail.com }}{ }^{3}$,rahmahasibuan@yahoo.co.id ${ }^{2}$, srisetowati@unesa.ac.id ${ }^{3}$ \\ Habibah, Umaiyah. Rachma Hasibuan. Sri Setyowati. (2021). Keefektifan Literasi Digital untuk Meningkatkan \\ Kemampuan Berpikir Logis dan Mengungkapkan Bahasa Anak. Jurnal Pelita PAUD, \\ 6(1), 81-91. \\ doi: https://doi.org/10.33222/pelitapaud.v6i1.1427
}

Diterima:30-08-2021

Disetujui: 10-12-2021

Dipublikasikan: 25-12-2021

\begin{abstract}
Abstrak: Penelitian ini bertujuan untuk mengetahui keefektifan litersi digital terhadap peningkatan kemampuan berpikir logis dan mengungkapkan bahasa anak usia dini. Merupakan penelitian kuantitatif dengan metode eksperimen yang dilakukan di Taman Kanak-Kanak Aisyiyah Cabang Ngagel Surabaya dengan sampel 96 anak, adapun data yang diperoleh melalui observasi dan dokumentasi kemudian dianalisis menggunakan statistik dengan Uji-t dengan bantuan SPSS 25 for windows. Hasil penelitian menunjukkan Keefektifan literasi digital untuk meningkatkan kemampuan berpikir logis dan mengungkapan bahasa pada anak usia dini yang diterapkan dalam pembelajaran. Terdapat perbedaan nilai rata-rata kemampuan berpikir logis pada anak usia dini yakni kelompok eksperimen lebih besar pengaruhnya dari pada kelompok kontrol. Uji-t membuktikan bahwa $\mathrm{H}_{0}$ ditolak dan $\mathrm{H}_{\mathrm{a}}$ diterima yang di ketahui dari nilai t-hitung adalah 2.222 lebih besar dari nilai t-tabel yaitu 1.98552. Efektifitas literasi digital dalam pembelajaran sangat berpengaruh dalam meningkatkan kemampuan mengungkapkan bahasa anak usia dini secara signifikan.
\end{abstract}

Kata Kunci : Literasi Digital, Berpikir Logis, dan Mengungkapkan Bahasa

Abstract: This study aims to determine the effectiveness of digital literacy to increase logical thinking skills and express language in early childhood. This is a quantitative research with experimental methods conducted at Aisyiyah Kindergarten, Ngagel Surabaya Branch with a sample of 96 children, while the data obtained through observation and documentation were then analyzed using statistics with t-test with the help of SPSS 25 for windows. The results show the effectiveness of digital literacy to improve logical thinking skills and express language in early childhood which is applied in learning. There is a difference in the average value of logical thinking ability in early childhood, namely the experimental group has a greater influence than the control group. The t-test proves that $\mathrm{HO}$ is rejected and $\mathrm{Ha}$ is accepted which is known from the t-count value is 2.222 which is greater than the t-table value of 1.98552. The effectiveness of digital literacy in learning is very influential in increasing the ability to express language in early childhood significantly.

Keywords: Digital Literacy, Logical Thinking, and Expressing Language

(C) 2021 Umaiyah Habibah, Rachma Hasibuan' Sri Setyowati Under the license CC BY-SA 4.0

http://jurnal.upmk.ac.id/index.php/pelitapaud 
P ISSN 2548-6284 E ISSN 2615-0360

Vol. 6 No. 1 Desember 2021

\section{PENDAHULUAN}

Perkembangan zaman yang semakin maju mendorong perkembangan ilmu pengetahuan dan teknologi yang ditandai dengan perkembangan pesat di bidang informasi dan teknologi, keberadaan teknologi yang sangat canggih pada saat ini dapat menjadi sarana fasilitas pemenuhan kebutuhan setiap manusia. Kecanggihan dan kelengkapan teknologi dari zaman ke zaman semakin terlihat bervariatif seperti halnya teknologi yang berupa gadget, laptop, alat elektronik rumah tangga, alat elektronik untuk membantu pekerjaan manusia di perkantoran atau industri-industri besar dan lain sebagainya, sedangkan yang paling banyak diminati pada saat ini adalah gadget. Gaya hidup masyarakat yang semakain bergulir mengikuti perkembangan zaman tidak dapat dilepaskan dari kebutuhan akan teknologi yang begitu besar dan hal ini sangat berdampak pada nilai-nilai budaya, berpikir kritis dan yang lainnya.

Saat ini pemakaian teknologi seperti halnya gadget bukan hanya para pekerja yang benarbenar membutuhkan, tetapi dari semua kalangan rata-rata sudah menggunakan gadget ini sebagai salah satu gaya hidup, baik dari usia dini hingga usia dewasa. Bahkan bisa saja terjadi beberapa orang menghabiskan waktu setiap harinya dengan gadget, dan kebiasaan ini pada akhirnya tidak jarang timbul ketergantungan dengan alat teknologi tersebut baik dikalangan anak usia dini dan kalangan orang dewasa. Oleh karena itu, dari kebiasaan pemanfaatan teknologi pastinya ada dampak positif dan negatif. Dampak negatif ini akan banyak didominasi anak usia dini apabila pemahaman akan literasi digitalnya masih belum anak fahami. Karena sejak usia dini anak menyadari keberadaan teknologi, dan pastinya karena rasa keingintahuan anak, maka anak akan menggunakannya. Oleh karena itu literasi digital harus dikenalkan sesuai dengan kebutuhannya sehingga dampak negatif yang diperolehnya dapat diminimalkan dan dampak positif yang bisa diperoleh anak-anak tersebut.

Dampak positif dari perkembangan dan pemanfaatan teknologi pada anak usia dini adalah dapat mencari permainan yang edukatif, belajar tanggap teknologi, dapat mencari informasi yang dibutuhkan dapat melatih fungsi otak, mempermudah komunikasi, mempermudah dalam mengakses ilmu pengetahuan, dalam
Keeefktifan Literasi Digital ....

Umaiyah Habibah'1 Rachma Hasibuan² Sri Setyowati

sebuah penelitian oleh (Haugland, 1992),menunjukkan bahwa anak usia 3-4 tahun yang telah menggunakan teknologi untuk mendukung kegiatan belajarnya mempunyai tingkat perkembangan yang lebih besar dibandingkan dengan anak yang tidak mempunyai pengalaman dengan teknologi. Tingkat perkembangan ini mencakup kecerdasan, keterampilan, verbal dan nonverbal, pengetahuan struktural, ingatan jangka panjang, ketangkasan manual, penyelesaian masalah, abstraksi dan kemampuan konseptual. Manfaat yang diterima anak ini juga tergantung dari penggunaannya dan untuk apa menggunakannya serta seberapa penting anak menggunakan media tersebut.

Literasi digital jika dapat dipahami dan diarahkan dengan baik akan menghasilkan yang positif. Adapun dampak negatifnya juga muncul jika anak usia dini tidak diarahkan dalam pemahamannya akan kebutuhan digital tersebut, anak-anak juga termasuk pengguna teknologi yang tinggi, tumbuh di era revulusi digital memandang layar atau tablet adalah aktivitas rutin, hal inilah yang akan timbul kekhawatiran atau dampak negatif jika tanpa bimbingan dan pemantauan ataupun pengarahan yang tepat. Diantara dampak penggunaan fasilitas perkembangan digital adalah bahaya radiasi terhadap anak, terkena ciber bullying, anak akan menjadi kencanduan, hambatan terhadap perkembangan, lambatnya memahami pelajaran, berisiko terhadap perkembangan psikologi anak sebagaimana yang nyatakan oleh (Kurnia, 2017)

Dampak lain dari revolusi digital yang tidak mendapat pantauan dan bimbingan adalah kecanduan pada teknologi, teraksesnya tontonan yang tidak selayaknya ditonton anak-anak dan lain sebagainya, sehingga menimbulkan terganggunya beberapa aspek perkembangan anak. Dengan begitu banyaknya efek negatif dari revolusi teknologi terhadap anak-anak, maka sangatlah perlu orang tua dan guru memahami betul apa sebenarnya literasi digital yang seharusnya di manfaatkan anak-anak usia dini bukan sekedar bermain melainkan lebih diarahkan kepada permainan edukatif yang dapat merangsang berkembangan kognitif anak dan perkembangan bahasa anak (Muhammad Aspar, Imam Mujtaba, Mutiarani Mutiarani, 2020).

Kondisi yang terjadi pada saat ini banyaknya anak usia dini yang kecenderungan untuk bermain dengan gadget atau teknologi untuk bernain game 
PISSN 2548-6284 E ISSN 2615-0360

Vol. 6 No. 1 Desember 2021

ataupun yang lainnya akan tetapi masih rendahnya pemahaman anak terhadap pemanfaatn literasi digital, rendahnya anak-anak dalam menerapkan pengetahuan dan pengalaman dalam kontesk yang baru, serta rendahnya penguasaan persiapan membaca pada anak usia dini yang disebabkan dengan kecenderungannya anak-anak bermain gadget atau teknologi tanpa adanya nilai penegtahuannya ataupun muatan pembelajaran.

Kondisi tersebut menjadikan tantangan tersendiri untuk guru-guru lebih melakukan inovasi pembelajaran yang juga mengarahkan pada media teknologi, guru dapat menfasilitasi dalam melakukan pembelajaran yang menggunakan media teknologi tersebut. Karena dengan perkembangan dunia teknologi yang semakin maju para guru juga dituntut ikut serta mengimbangi untuk pengetahuannya dan bisa diimplementasikan ke dunia pendidikan sehingga inovasi pembelajaran dapat memaksimalkan hasil yang diperoleh oleh anak-anak .

Berdasarkan kenyataan diatas yang melatarbelaknagi penelitian ini adalah kecenderungan anak pada media teknologi yang sudah sangat tinggi sedangkan pemahaman pada pemanfaatan dan penggunaan literasi digital kurang maksimal

Sebagai sampel penelitian ini di Taman Kanakkanak Aisyiyah cabang Ngagel Surabaya tersebut juga terjadi perkembangan kognitif anak khususnya kemampuan berpikir logis dan kemampuan mengungkapkan bahasa pada anak usia 5-6 kurang maksimal. faktor penyebabnya karena penggunaan media dalam kegiatan pembelajaran kurang maksimal, seperti halnya dalam pembelajaran yang menerangkan tentang kalsifikasi binatang, pekerjaan dan tanaman yang tidak mungkin didatangkan perlu adanya pemanfaatan media yang menaraik dan inovatis untuk menjelaskan dengan baik sehingga pembelajaran bisa menraik, menyenangkan dan hasilnya dapat maksimal.

Selain perkembangan kognitif, perkembangan bahasa juga berkembang pesat pada anak usia dini. Kurva perkembangan kognitif dan bahasa pada anak usia dini mengalami masa-masa perkembangan emas (golden ages). Untuk itulah perlunya pendidik dalam memberikan pemahaman literasi digital. Guru dan orang tua harus betul-betul dapat memberikan pemahaman yang tepat. Karakteristik anak pada masa usia dini sangat mudah menyerap berbagai informasi
Keeefktifan Literasi Digital ....

Umaiyah Habibah' Rachma Hasibuan² Sri Setyowati

teknologi dan ini harus diimbangi dengan sisi keamanan ilmu pengetahuan, ketrampilan, sikap dan pengalaman yang diserap oleh dirinya. Keberadaan masa era digitalisasi sudah terjadi, suka atau tidak suka, mau atau tidak mau harus dihadapi dengan arif dan bijaksana karena akan mempengaruhi kehidupan anak-anak pada saat ini. Adapun aspek perkembangan bahasa pada anak usia dini juga tidak kalah pentingnya untuk diperhatikan dalam proses perkembangan anak. Kemampuan berbahasa dapat menjadikan indikator seluruh perkembangan anak

Penglihatan dan pendengaran anak harus dijaga, perkembangan bahasa yang tepat, efektif, sopan dan santun harus dibimbing dan diarahkan, kognitif dengan penalarannya dan rasa keingin tahuan yang sangat tinggi terhadap apa yang terjadi harus diawasi agar tetap aman dan terjaga dari pengetahuan, informasi yangtidak sesuai dengan tahapan perkembangan dan kebutuhannya. Untuk itulah maka kewajiban lingkunganlah baik itu lingkungan keluarga dan lingkungan sekolah yang harus bijak dalam memberi pemahaman yang betul terhadap pemanfatan literasi digital serta urgensi literasi digital terhadap perkembangan anak, baik itu perkembangan kognitif dan bahasa serta yang lainnya.

Kondisi ideal anak usia 5-6 tahun dalam Permendikbud Nomor 137 tahun 2014 tentang standar nasional pendidikan anak usia dini menyatakan perkembangan bahasa khususnya mengungkapkan Bahasa anak usia 5-6 tahun yaitu kemampuan dalam menjawab pertanyaan yang lebih kompleks, berkomunikasi secara lisan serta menyebutkan kelompok gambar yang memiliki bunyi yang sama.

Kenyataan dilapangan berdasarkan observasi yang dilakukan pada Anak usia dini disalah satu lembaga yang digunakan peneliana membuktikan bahwa dalam mengungkapkan Bahasa anak usia dini masih rendah, anak-anak saat kegiatan tanya jawab sering terlihat diam, kurang antusias saat bercerita didepan kelas

Pada aspek perkembangan kognitif anak usia dini berbeda dengan orang yang sudah dewasa, karena pada dasarnya semua aspek perkembangan memiliki tahapan termasuk juga pada aspek perkembangan kognitif. Tahapan perkembangan kognitif itu sendiri menurut Jean Piaget untuk anak usia dini atau anak usia Taman Kanak-kanak berada pada tahapan praoperasional (2-7 tahun). 
PISSN 2548-6284 E ISSN 2615-0360

Vol. 6 No. 1 Desember 2021

Pemikiran anak masih intuitif, irreversible (satu arah), dan belum logis. Egosentris anak masih sangat tinggi, sehingga belum mampu melihat perpektif orang lain (Santrock, 2007), (Suyanto, 2005). Meskipun pemikiran anak dikatakan belum logis akan tetapi pada usia ini kecerdasan anak hampir mencapai $80 \%$, sehingga perlu adanya stimulus yang baik sesuai bagi anak dan dapat mengoptimalkan semua aspek perkembangannya, terutama pada aspek perkembangan kognitif.

Orang tua dapat mendeteksi keterlambatan atau kelainan pada anak dari kemampuan berbahasa. Pentingnya perkembangan bahasa bagi anak usia dini juga dijelaskan oleh (Hurlock, 1997) bahwa usia 3-6 tahun anak sedang dalam masa peralihan dari masa egosentris menuju kemasa sosial. Perkembangan bahasa mencakup komunikasi non verbal dan verbal. Bahasa dijadikan landasan seorang anak untuk mempelajarihal-hal baru dalam kehidupan. Para peneliti di bidang psikologi perkembangan mengatakan bahwa perkembangan bahasa lebih cepat dari aspekaspek perkembangan lainnya, meskipun sebagian anak terkadang ditemukan juga perkembangan motorik atau perkembangan lainnya yang lebih dulu.

Salah satu strategi untuk menstimulus perkembangan kognitif khususnya kemampuan berpikir logis dan perkembangan Bahasa khususnya dalam hal menggungkapkan Bahasa dengan menggunakan media permainan audi visual atau pembelajaran berbasis ICT (Information and Communication Technologies) yang dapat menarik dan mengalihkan anak-anak dari pengunaan digital yang tidak tepat guna menjadi pemakaian digital yang bisa dijadikan sarana edukatif yang dapat merangsang perkembangan baik kognitif anak maupun perkembangan bahasa anak. Penggunaan literasi digital yang tepat sasaran dan menjadi media interaktif yang efektif, maka sudah pasti akan menjadi pendukung dan pengembangan pembelajaran(Baiti, 2020).

Penggunaan yang disengaja dalam literasi digital memerlukan guru dan administrator anak usia dini untuk memiliki informasi dan sumber daya mengenai sifat alat ini dan aplikasi penggunaannya pada anak-anak, dengan pertimbangan khusus harus tetap diberikan kepada pengguna teknologi pada anak usia dini. Sehingga dapat terarah dalam penggunaannya dan apa saja yang bisa dipilih untuk menggunakannya
Keeefktifan Literasi Digital .... Umaiyah Habibah' Rachma Hasibuan² Sri Setyowati ${ }^{3}$

dan dapat menumbuhkan serta menstimulus perkembangan kognitif dan bahasa anak serta perkembangan yang lainnya

Berawal dari latar belakang tersebut peneliti memilih judul "Keefektifan Literasi Digital Untuk Meningkatkan Kemampuan Berpikir Logis Dan Mengungkapkan Bahasa Pada Anak Usia Dini”. Tujuan yang akan dicapai adalah 1). Untuk mengetahui Keefektifan Literasi Digital dalam Meningkatkan Kemampuan Berpikir Logis Anak Usia Dini; dan 2). Untuk mengetahui Keefektifan Literasi Digital dalam Meningkatkan Kemampuan Berpikir Logis Dan Mengungkapkan Bahasa Pada Anak Usia Dini.

\section{METODE PENELITIAN}

Penelitian dilakukan untuk mencari pemecahan, pemecahan masalah dalam penelitian juga membutuhkan proses yang diperlukan metode yang sesuai sehingga dapat menghasilkan pengetahuan yang ilmiah. Metode penelitian adalah cara yang digunakan oleh peneliti untuk mendapatkan data informasi mengenai berbagai hal yang berkaitan dengan masalah yang diteliti sebagaimana yang dinyatakan oleh (Darmawan, 2013).

Penelitian ini tentang Keefektifan Literasi Digital Untuk Meningkatkan Kemampuan Berpikir Logis Dan Mengungkapkan Bahasa Pada Anak Usia Dini dan penelitian ini menggunakan pendekatan penelitian kuantitatif. Penelitian kuantitatif dilakukan dengan cara menggambarkan data ke dalam bentuk angka-angka. Penelitian ini digunakan untuk menguji sebuah hipotesis dari hubungan antar variabel penelitian.

Penelitian ini dilakukan dengan menggunakan metode Eksperimen. Menurut (Sugiyono, 2017) metode eksperimen merupakan metode penelitian yang digunakan untuk mencari pengaruh perlakuan tertentu terhadap yang lain dalam kondisi yang terkendali. Adapun variabelnya dalam penelitian ini adalah tediri dari (1) keefektifan Literasi Digital (X) sebagai variabel bebas atau independen, (2) Berpikir $\operatorname{Logis}\left(\mathrm{Y}_{1}\right)$, dan (3) Mengungkapkan Bahasa $\left(\mathrm{Y}_{2}\right)$.

Desain penelitian termasuk rancangan, rencana dan stuktur penyelidikan yang disusun sedemikain rupa sehingga peneliti akan memperoleh jawaban untuk pertanyaan penelitiannya. Rancangan penelitian eksperimen untuk pengujian hipotesis penelitian menurut (Sugiyono, 2017)ada empat kelompok 
PISSN 2548-6284 E ISSN 2615-0360

Vol. 6 No. 1 Desember 2021

Eksperimen yakni; (1) Pre Eksperimen (Pre Eksperimenin Design), (2) Eksperimen Sejati (True Experimental Design), (3) Factorial Experimental, dan (4) Eksperimen Semu (Quasi Experimental Design).

\section{HASIL PENELITIAN}

Penelitian ini bertujuan untuk mengetahui efektifitas literasi digital untuk meningkatkan memampuan berpikir logis pada anak usia dini dan meningkatkan kemampuan mengungkapkan bahasa anak usia yang diambil dari TK Aisyiyah Cabang Ngagel Surabaya dengan sampel penelitian adalah TK Aisyiyah 39 dan TK Aisyiyah 21 . Jumlah data dalam penelitian ini sebanyak 96 anak yaitu TK aiyiyah 39 sejumlah 53 anak, TK Aisyiyah 21 sejumlah 43 anak. Penelitian ini dilaksanakan pada bulan Juni sampai dengan bulan Agustus 2020. Penelitian ini menggunakan desain penelitian Quasi Eksperimental Design dengan pola Nonequivalent Kontrol Group Design. Sampel pada penelitian ini dibagi menjadi 2 kelompok yaitu kelompok eksperimen dan kelompok kontrol, dimana kedua kelompok ini memiliki sifat dan karakteristik yang sama.

Kegiatan penelitian ini diawali dengan memberikan observasi awal mengenai meningkatkan kemampuan mengungkapkan bahasa anak usia dini. Observasi diawal dilakukan pada kedua kelompok baik kelompok eksperimen maupun kelompok kontrol. Observasi diawali bertujuan untuk mengetahui meningkatkan kemampuan mengungkapkanbahasa anak. Observasi awal dilakukan dengan teknik penilaian observasi dan dokumentasi dari kegiatan pembelajaran anak sebelum diberikan perlakuan. Setelah peroses observasi awal selesai, langkah berikutnya adalah pelaksanaan perlakuan. Dalam tahap ini kelompok eksperimen yang diberikan perlakuan, diberikan kegiatan pembelajaran yang menggunakan perangkat digital (leptop,/ computer, Proyektor lcd dll) 2 kali seminggu selama 2 minggu. Kegiatan tersebutdilakukan selama 30-45 menit pada saat kegiatan pembelajaran berlangsung dengan menggunakan tema tanaman. kegiatan tersebut dilakukan di ruangan sekolah yang terfasilitasi dengan alat digital. Pada proses pembelajaran tersebutkegiatan digunakan untuk belajar dan pembelajaran mengenalkan tanaman
Keeefktifan Literasi Digital .... Umaiyah Habibah' Rachma Hasibuan² Sri Setyowati

menggunakan teknologi digital, pengenalan tentang ciptaan Allah yang diantara salah satunya adalah tanaman hias dari bagian-bagiannya, ciricirinya dan lain sebagainya. Menyebutkan bagianbagian dari jenis tanaman hias yakni bunga mawar. Ketepatan mengungkapkan bahasa dalam menyebutkan bagian-bagian dari tanaman yang ditanyakan di layar monitor. Kemampuan berpikir kritis dan logis anak akan dapat dinilai ketika anak melaksanakan kegiatan diakhir kegiatan dengan post tes yang sudah disediakan dilayar monitor.

Sementara itu kelompok kontrol tidak diberi perlakuan, mengikuti pembelajaran rutin sesuai tema yang dijadwalkan guru. Langkah berikutnya yaitu memberikan observasi akhir. Proses pelaksanaan observasi yang sama. Observasi akhir ini dilakukan juga pada kedua kelompok kontrol maupun eksperimen. Obsevasi akhir ini bertujuan untuk mengetahui Keefektifan literasi digital untuk meningkatkan memampuan berpikir logis pada anak usia dini dan kemampuan mengungkapkan bahasa pada anak usia dini, setelah adanya pemberian perlakuan bagi kelompok eksperimen maupun kontrol. Kemudian observasi awal dan akhir keduanya dibandingkan dengan tujuan untuk mengetahui ada tidaknya perbedaan hasil observasi dari kelompok kontrol dan kelompok eksperimen. Hasil data yang diperoleh dari observasi awal dan akhir dibandingkan untuk menguji hipotesis.

\section{Hasil Penerapan Keefektifan Literasi Digital} Untuk Meningkatkan Kemampuan Berpikir Logis pada anak usia dini

Bagian ini membahas tentang hasil penerapan keefektifan literasi digital untuk meningkatkan memampuan berpikir logis pada anak usia dini. Keefektifan literasi digital untuk meningkatkan memampuan berpikir logis pada anak usia dini ini dilakukan pada kelompok eksperimen. Kelompok eksperimen diberikan treatmen yaitu dengan kegiatan pembelajaran menggunakan alat digital yang sudah disediakan 2 kali setiap minggu selama 2 minggu. Kegiatan tersebut dilakukan selama 30-45 menit pada saat kegiatan pembelajaran. Sementara kelompok kontrol tidak diberiperlakuan, mengikuti pembelajaran rutin yang dijadwalkan guru.

Hasil dari penerapan kegiatan tersebut dapat dilihat melalui perbedaan perolehan skor yang menunjukan kemampuan anak dalam melakukan kegiatan pada kelompok kontrol dan eksperimen. 
PISSN 2548-6284 E ISSN 2615-0360

Vol. 6 No. 1 Desember 2021

Kegiatan ini terdiri dari beberapa item pernyataan. Keefektifan literasi digital untuk meningkatkan kemampuan berpikir logis pada anak usia dini dapat dilihat melalui rata-rata kelompok perolehan skor anak yang diperoleh melalui observasi. Kegiatan observasi untuk mengetahui kemampuan pada anak yang dilakukan sebanyak dua kali yaitu observasi awal dan akhir. Hasil dari penerapan keefektifan literasi digital untuk meningkatkan memampuan berpikir logis pada anak usia dini tersebut dapat dilihat melalui tabel perbandingan rata-rata kelompok pada variabel keefektifan pemanfaatan digital dalam belajar pada saat observasi awal dan observasi akhir pada kelompok kontrol dan eksperimen, yaitu sebagai berikut:

Tabel 1. Perbandingan perolehan skor observasi awal dan akhir Keefektifan Literasi Digital

\begin{tabular}{llll}
\hline & $\begin{array}{l}\text { Observas } \\
\text { i } \\
\text { awal }\end{array}$ & $\begin{array}{l}\text { Observ } \\
\text { asi } \\
\text { akhir }\end{array}$ & Kenaikan \\
\hline $\begin{array}{l}\text { Kelompok } \\
\text { kontrol }\end{array}$ & 2.3 & 2.5 & 0.2 \\
\hline $\begin{array}{l}\text { Kelompok } \\
\text { eksperimen }\end{array}$ & 2.4 & 3 & 0.6 \\
\hline
\end{tabular}

Dari tabel diatas dapat disajikan grafik perbandingan rata-rata perolehan skor variabel penerapan efektifitas litersi digital dalam pembelajaran anak di observasi awal dan akhir kelompok kontrol dan eksperimen.

\section{BERPIKIR LOGIS}

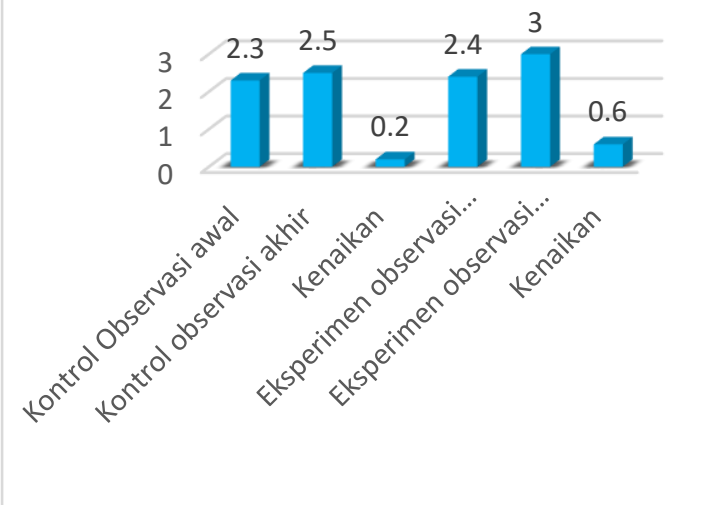

Grafik. 1. Perbandingan perolehan skor Keefektifan Literasi Digital
Keeefktifan Literasi Digital .... Umaiyah Habibah' Rachma Hasibuan² Sri Setyowati

Berdasarkan tabel 1 dan grafik 1 dapat disimpulkan bahwa nilai rata-rata Keefektifan literasi digital untuk meningkatkan memampuan berpikir logis pada anak usia dini pada kelompok kontrol yaitu pada observasi awal sebesar 2.3 dapat dibulatkan menjadi 2 yang berarti anakanak dalam penerapan keefektifan literasi digital untuk meningkatkan memampuan berpikir logis pada anak usia dini rata-rata pada kategori cukup berkembang. Rata-rata observasi akhir padakelompok kontrol sebesar 2.5 dapat dibulatkan menjadi 2 yang berarti anak-anak dalam penerapan Keefektifan literasi digital untuk meningkatkan memampuan berpikir logis pada anak usia dini kategori cukup berkembang. Pada kelompok kontrol rata-rata observasi awal akhir mengalami kenaikan sebesar 0.2

Sedangkan nilai rata-rata kelompok eksperimen Keefektifan literasi digital untuk meningkatkan memampuan berpikir logis pada anak usia dini pada kelompok eksperimen yaitu pada observasi awal sebesar 2.4 dapat dibulatkan menjadi 2 yang berarti anak-anak dalam penerapan Keefektifan literasi digital untuk meningkatkan memampuan berpikir logis pada anak usia dini rata-rata pada kategori cukup berkembang. Rata-rata observasi akhir kelompok eksperimen sebesar 3 dapat dibulatkan menjadi 3 yang berarti anak-anak dalam penerapan Keefektifan literasi digital untuk meningkatkan memampuan berpikir logis pada anak usia dini termasuk kategori berkembang sesuai harapan. Pada kelompok eksperimen ratarata kelompok observasi awal dan akhir mengalami kenaikan sebesar 0.6. Dari data diatas kenaikan rata-rata kelompok observasi awal dan observasi akhir kelompok eksperimen lebih besar dari pada kelompok kontrol. Hal ini dikarenakan kelompok eksperimen mendapat perlakuan dari penerapan Keefektifan Literasi Digital dalam kegiatan pemebelajaran tersebut.

Hasil keefektifan literasi digital untuk meningkatkan kemampuan mengungkapkan bahasa pada anak.

Bagian ini membahas tentang hasilKeefektifan literasi digital untuk meningkatkan kemampuan mengungkapkan bahasa pada anak usia dini. Keefektifan literasi digital untuk meningkatkan kemampuan mengungkapkan bahasa pada anak usia dini. Penerapan kegiatan ini dilakukan pada kelompok eksperimen. Kelompok eksperimen diberikan treatmenya 2 kali setiap minggu selama 2 minggu. Kegiatan ini dilakukan selama 30-45 
PISSN 2548-6284 E ISSN 2615-0360

Vol. 6 No. 1 Desember 2021

menit pada saat kegiatan pembelajaran dengan menggunakan tema tanaman. Sementara kelompok kontrol tidak diberi perlakuan, mengikuti pembelajaran rutin yang dijadwalkan guru.

Hasil dari penerapan kegiatan tersebut dapat dilihat melalui perbedaan perolehan skor yang menunjukan keefektifan literasi digital untuk meningkatkan kemampuan berpikir logis dan kemampuan mengungkapkan bahasa pada anak usia dini pada kelompok kontrol dan eksperimen.kemampuan bahasa anak pada kegiatan ini, dalam penelitian terdiri dari beberapa pernyataan. kemampuan mengungkapkan bahasa pada anak usia dini dapat dilihat melalui rata-rata kelompok perolehan skor anak yang diperoleh melalui observasi. Kegiatan observasi untuk mengetahui kemampuan mengungkapkan bahasa pada anak usia dini dilakukan sebanyak 2 kali yaitu observasi awal dan akhir. Hasil dari penerapan literasi digital pada pembelajaran anakdapat dilihat melalui table perbandingan ratarata kelompok pada variabel kemampuan mengungkapkan bahasa pada anak usia dini pada saat observasi awal dan observasi akhir pada kelompok kontrol dan eksperimen, yaitu sebagai berikut:

Tabel 2. Perbandingan perolehan skor observasi awal dan akhir

\begin{tabular}{llll}
\hline & $\begin{array}{l}\text { Observas } \\
\text { i awal }\end{array}$ & $\begin{array}{l}\text { Observas } \\
\text { i akhir }\end{array}$ & $\begin{array}{l}\text { Kenaik } \\
\text { an }\end{array}$ \\
\hline $\begin{array}{l}\text { Kelompok } \\
\text { kontrol }\end{array}$ & 2.2 & 2.4 & 0.2 \\
\hline $\begin{array}{l}\text { Kelompok } \\
\text { eksperimen }\end{array}$ & 2.5 & 3.1 & 0.6 \\
\hline
\end{tabular}

Dari tabel diatas dapat dijadiikan grafik perbandingan rata-rata perolehan skor variabel penerapan litersi digital dalam pebelajaran anak pada observasi awal dan akhir kelompok kontrol dan eksperimen.
Keeefktifan Literasi Digital .... Umaiyah Habibah' Rachma Hasibuan² Sri Setyowati

\section{MENGUNGKAPKAN BAHASA}

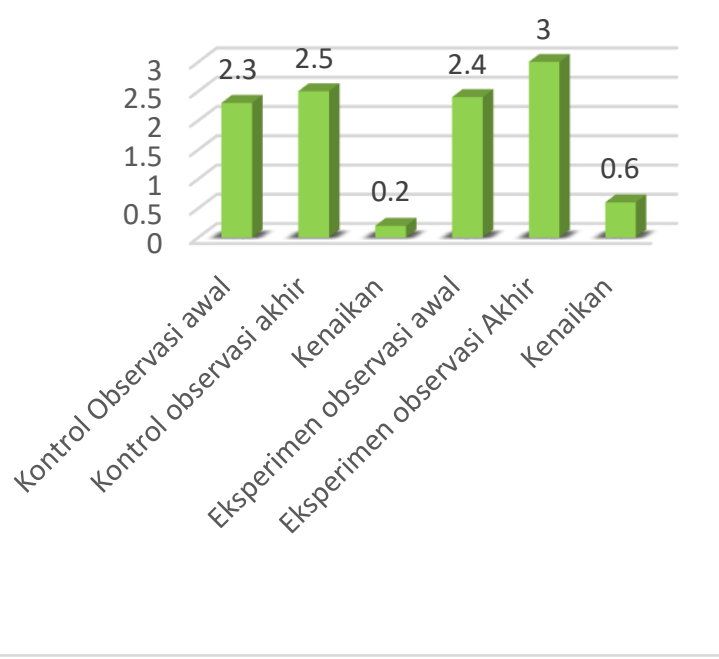

Grafik 2. perbandingan perolehan skor kemampuan mengungkapkan bahasa

Berdasarkan tabel 2 dan grafik 2 dapat disimpulkan bahwa nilai rata-rata kemampuan mengungkapkan bahasa pada anak usia dini pada kelompok kontrol yaitu pada observasia awal sebesar 2.2 dapat dibulatkan menjadi 2 yang berarti anak-anak dalam hal tersebut pada kategori cukup berkembang. Rata-rata observasi akhir pada kelompok kontrol sebesar 2.4 dapat dibulatkan menjadi 2 yang berarti anak-anak dalam kemampuan mengungkapkan bahasa pada anak usia dini kategori cukup berkembang. Pada kelompok kontrol rata-rata observasi awal akhir mengalami kenaikan sebesar 0.2 Sedangkan nilai rata-rata kelompok kelompok eksperimen yaitu pada observasi awal sebesar 2.5 dapat dibulatkan menjadi 2 yang berarti anak-anak dalam kemampuan mengungkapkan bahasa pada anak usia dini rata-rata pada kategori cukup berkembang. Rata-rata observasi akhir kelompok eksperimen sebesar 3.1 dapat dibulatkan menjadi 3 yang berarti anak-anak dalam kemampuan mengungkapkan bahasa pada anak usia dini termasuk kategori berkembang sesuai harapan. Pada kelompok eksperimen rata-rata kelompok observasi awal dan akhir mengalami kenaikan sebesar 0.6.

Dari data diatas kenaikan rata-rata kelompok observasi awal dan observasi akhir kelompok eksperimen lebih besar dari pada kelompok kontrol. Hal ini dikarenakan kelompok 
P ISSN 2548-6284 E ISSN 2615-0360

Vol. 6 No. 1 Desember 2021

eksperimen mendapat perlakuan penerapan literasi digital dalam waktu pembelajaran.

\section{PEMBAHASAN}

Semakin berkembangnya dunia pendidikan yang sesuai perkembangan zaman dituntut para pembelajar untuk selalu melakukan inovasiinovasi baru dengan menyesuaikan kebutuhan anak sesuai zamannya. Salah satu upaya dalam memenuhi kebutuhan inovasi pembelajaran dan memenuhi kebutuhan anak sesuai zamannya ada dengan menggunakan pembelajaran berbasis ICT atau pembelajaran yang menggunakan teknologi. Pembelajarn dengan menekankan pada kemampuan literasi digital pada pembelajaran anak usia dini tersebut dinilai efektif apa tidak untuk meningkatkan kemampuan berpikir logis dan kemampuan mengungkapkan bahasa pada anak usia dini.

\section{Kefektifan Literasi Digital untuk Meningkatkan Kemampuan Berpikir Logis pada anak usia dini}

Keefektifan Literasi Digitalberpengaruh secara signifikan dalam meningkatkan kemampuan berpikir logis pada anak usia dini. Pelaksanaan penelitian ini terbagi menjadi dua kelompok penelitianya itu kelompok kontrol dan kelompok eksperimen. Kedua kelompok ini memiliki karakteristik dan sifat yang sama atau hampir sama. Hal ini terbukti dengan uji homogenitas dengan hasil untuk variabel pemanfaatan literasi digital dalam pembelajaran adalah 0.221 nilai tersebut lebih besar dari signifikasi sebesar 0.05 sehingga data dari variabel tesrebut adalah homogen.

Kelompok eksperimen diberikan treatmen yaitu pemanfaatan literasi digital dalam pembelajaran 2 kali seminggu selama 2 minggu. pemanfaatanliterasi digital dalam pembelajaran ini dilakukan selama 30-45 menit pada saat kegiatan pembelajaran dilakukan di ruangan yang luas atau halaman sekolah. Sementara kelompok kontrol tidak diberi perlakuan hanya mengikuti pembelajaran yang dijadwalkan oleh guru.

Pemanfaatan literasi digital dalam pembelajaran berpengaruh secara signifikan terhadap kemampuan berpikir logis pada anak usia dini. Hal ini terbukti bahwa ada perbedaan antara nilai dari kemampuan anak berpikir logis anak yang mengikuti pemanfaatan literasi digital dalam pembelajaran. Pengujian hasil penelitian tersebut menguji melalui uji-tyang berarti pemanfaatan
Keeefktifan Literasi Digital .... Umaiyah Habibah' Rachma Hasibuan² Sri Setyowati

literasi digital dalam pembelajaran secara signifikan berpengaruh terhadap kemampuan berpikir logis pada anak usia dini yang diteliti di Taman Kanak-Kanak Aisyiyah Cabang Ngagel Surabaya.

Pelaksanaan penelitian di Taman Kanak-Kanak Aisyiyah cabang Ngagel Surabaya ini menggunakan treatmen pemanfaatan literasi digital dalam pembelajaran. Pemanfaatan literasi digital dalam pembelajarandilakukan selama 3045 menit pada saat kegiatan pembelajaran berlangsung dengan menggunakan tema tanaman. Pemanfaatan literasi digital dalam pembelajaranini dilakukan di ruang kelas. Pemanfaatan literasi digital dalam pembelajaranini berpengaruh pada aspek perkembangan anak.

Hasil penelitian ini menemukan bahwa skor ratarata kelas untuk kemampuan berpikir logis pada kelas eksperimen lebih tinggi yaitu sebesar 2.92 dari pada anak kelompok kontrol yaitu sebesar 2.23. hal ini dikarenakan kelas eksperimen mendapatkan treatmen berupa Pemanfaatan literasi digital dalam pembelajaransedangkan kelas kontrol tidak mendapatkan treatmen. Dalam penelitian ini, kegiatan pemanfaatan literasi digital dalam pembelajaranmemungkinkan anak untuk bermain menggunakan teknologi untuk menggali informasi dalam pembelajaran. Kegiatan pemanfaatan literasi digital dalam pembelajaranini terdiri dari pengenalan jenis tanaman ciptaan Allah serta pengenalan jenis tanaman hias (kelompok bunga mawar) dan bagian bagiannya, menyebutkan bagianbagiannya dan mengelompokkan jenis bunga mawar.

Pemanfaatan literasi digital sangat efektif untuk menstimulus anak usia dini dalam berpikir logis karena dapat merangsang anak untuk membuat konsep didalam proses berpikir sebagaimana yang dikemukan oleh Piaget yakni salah satu tokoh psikologi perkembangan anak yang terdapat dalam buku, Psikologi Pendidikan: Teori dan Aplikasi dalam Proses Pembelajaran, menyatakan bahwa berpikir logis adalah kesadaran dari seseorang yaitu membuat suatu kata atau konsep di dalam proses berpikir.

Literasi digital untuk masa tertentu akan sangat dibutuhkan dalam pem belajaran baik pada tingkat anak usia dini hingga perguruan tinggi. Literasi ditital dirasa sangat perlu dijadikan salah satu media pembelajaran sesuai dengan perkembangan 
PISSN 2548-6284 E ISSN 2615-0360

Vol. 6 No. 1 Desember 2021

zaman. Pemanfaatan literasi digital secara efektif dalam pembelajaran dalam penelitian ini mendapat hasil yang signifikan dengan menigkatkannya kemmapuan anak untuk berpikir logis, hal ini sesui dengan penelitian (Sufa, Feri Faila, Setiawan, 2015), yang berjudul "Mengembagkan Kognisi Anak Usia Dini Melalui Pembelajaran Komputer" menyatakan bahwa melalui penerapan pembelajaran komputer pada anak usia dini tersebut dapat mengembangkan kognitif anak. Kognitif anak usia dini tersebut diantaranya adalah berpikir logis. Adapun Penelitian yang dilakukan oleh (Rahmawati, Heni dan Tharmizi, 2018) dengan judul "Pengaruh Media Pembelajaran Abjad Berbasis Mobile Terhadap Peningkatan Kecerdasan Kognitif Studi Kasus Pada Pendidikan Anak Usia Dini Joyokusumo Kabupaten Banjarnegara". Hasil penelitiannya terdapat pengaruh media pembelajaran abjad yang memanfaatkan alat digital tersebut juga berpengaruh terhadap peningkatan kecerdasan kognitif siswa.

Berbeda dengan penelitian yang dilakukan oleh (Ellingson, 2016), "Interactive Technology Use in Early Childhood Programs to Enhance Literacy Development \& Early Literacy Development for Children with Cochlear Implants". Penelitian tersebut menyatakan bahwa anak dapat mengasah kemampuan keaksaraan dengan menggunakan teknologi sepanjang hari di sekolah sehingga dapat mengoptimalkan kemampuan keaksaraan. Hasil penelitiannya lebih menekankan pada kemampuan keaksaraan ketika anak memanfaatkan pembejaran mengguanakan teknologi digital.

Era digitalisasi yang tidak lepas dari dunia anak, tidak bisa dielakkan lagi, dengan demikian pembelajaranpun juga menuntut semakin inovatif agar pembelajaran semakin menyenangkan dan dapat menstimulus perkembangan anak usia dini. Dalam penelitian ini, kegiatan pembelajaran yang menggunakan pemamanfaatan digital menjadikan anak-anak belajar serasa bermain dengan memasukkan tema yang susai dengan standart pencapaian perkembangan anak tersebut.

Keefektifan literasi digital juga merupakan pembelajaran yang menyenangkan karena anakanak belajar dengan permainan edukatif melalui digital hal ini sejalan dengan penyataan (Clark, E, 2018)yang menyatakan bahwa dengan bermain anak-anak menjadi senang dan dapat
Keeefktifan Literasi Digital ....

Umaiyah Habibah' Rachma Hasibuan² Sri Setyowati3

mengembangkan perkembangan yang positif bagi pertumbuhan kognitif, afektif dan sosiukultural. Hal ini sesuai dengan prinsip bermain, bahwa kemampuan anak dapat dikembangkan melalui kegiatan bermain. Anak belajar dengan pengalaman bermainnya.

Dengan demikian maka penerapan pemanfaatan literasi digital dalam pembelajaranpada anak usia dini di Taman Kanak-Kanak Aisyiyah Cabang Ngagel Surabaya sangatlah bermanfaat, terutama dalam mengembangkan pemahaman literasi digital.

\section{Keefektifan literasi digital dalam pembelajaranterhadap kemampuan mengungkapkan bahasa pada anak usia dini} Pemanfaatan literasi digital dalam pembelajaranberpengaruh secara signifikan terhadap kemampuan mengungkapkan bahasa pada anak usia dini. Pelaksanaan penelitian ini terbagi menjadi dua kelompok penelitian yaitu kelompok kontrol dan kelompok eksperimen. Kedua kelompok ini memiliki karakteristik dan sifat yang sama atau hampir sama. Hal ini terbukti dengan uji homogenitas dengan hasil untuk variabel kemampuan mengungkapkan bahasa anak usia dini tersebut lebih besar dan signifikan sehingga data dari variabel kemampuan mengungkapkan bahasa pada anak usia dini ini adalah homogen (Simanjuntak, 2019).

Kelompok eksperimen diberikan treatmen yaitu Pemanfaatan literasi digital dalam pembelajaran ini dilaksanakan 2 kali seminggu selama 2 minggu. Pemanfaatan literasi digital dalam pembelajaran dilakukan selama 30-45 menit pada saat kegiatan pembelajaran dilakukan di ruangan. Sementara kelompok kontrol tidak diberi perlakuan hanya mengikuti pembelajaran yang dijadwalkan oleh guru.

Pemanfaatan literasi digital dalam pembelajaran berpengaruh secara signifikan terhadap kemampuan mengungkapakan bahasa pada anak usia dini anak. Hal ini terbukti bahwa ada perbedaan antara nilai dari kemmapuan mengungkapkan bahasa anak yang mengikuti Pemanfaatan literasi digital dalam pembelajaran. Pengujian hasil penelitian tersebut menguji melalui uji-t yang berarti pemanfaatan literasi digital dalam pembelajaransecara signifikan berpengaruh terhadap kemampuan mengungkapkan bahasa pada anak usia dini di Taman Kanak-Kanak Aisyiyah cabang Ngagel Surabaya. 
P ISSN 2548-6284 E ISSN 2615-0360

Vol. 6 No. 1 Desember 2021

Pelaksanaan penelitian di Taman Kanak-Kanak Aisyiyah cabang Ngagel Surabaya ini menggunakan treatmen berupa Pemanfaatan literasi digital dalam pembelajaran. Pemanfaatan literasi digital dalam pembelajaran dilakukan selama 30-45 menit pada saat kegiatan pembelajaran berlangsung dengan menggunakan tema tanaman. Pemanfaatan literasi digital dalam pembelajaran dilakukan di ruangan.

Skor rata-rata kelas untuk kemampuan mengungkapkan bahasa pada kelas eksperimen lebih tinggi hasilnya dari pada anak kelompok kontrol, hal ini dikarenakan kelas eksperimen mendapatkan treatmen berupa pemanfaatan literasi digital dalam pembelajaran sedangkan kelas kontrol tidak mendapatkan treatmen. Dalam penelitian ini, kegiatan pemanfaatan literasi digital dalam pembelajaran memungkinkan dapat mengemukakan idea atau gagasan baru pada pembelajaran yang baru, sehingga kemampuan anak dalam mengungkapkan bahasa meningkat. Hal ini mempunyai kesamaan hasil penelitian yang dilakukan oleh Berbeda dengan penelitian yang dilakukan oleh (Ellingson, 2016), "Interactive Technology Use in Early Childhood Programs to Enhance Literacy Development \& Early Literacy Development for Children with Cochlear Implants". Penelitian tersebut menyatakan bahwa anak dapat mengasah kemampuan keaksaraan dengan menggunakan teknologi sepanjang hari di sekolah sehingga dapat mengoptimalkan kemampuan keaksaraan. Hasil penelitiannya lebih menekankan pada kemampuan keaksaraan ketika anak memanfaatkan pembejaran mengguanakan teknologi digital. Dengan kemampuan keasksaraan anak dapat mengungkapkan bahasa dengan baik.

Penelitian yang menunjukkan hasil sama adalah penelitian yang dilakukan dilakukan oleh (Oladunjoye, 2013), "iPad an Computer Devices in preschool: A Tool For Literacy Development Among Teachers and Chilren in Preschool.Hasil dari penelitian Olayemi menyebutkan berbagai fungsi literasi digital dapat mendukung pengembangan bahasa pada anak usia dini. Perkembangan bahasa anak usia dini tersebut diantaranya adalah kemampuan anak dalam mengungkapkan bahasa.

Kemampuan berbahasa anak perlahan berkembang mengikuti tahapan perkembangannya. Perkembangan bahasa anak
Keeefktifan Literasi Digital .... Umaiyah Habibah' Rachma Hasibuan² Sri Setyowati

juga perlu adanya stimulus untuk mengembangkan dengan bagus sesuai dengan kondisi mental anak, karena perkembangan bahasa juga berkembang sesuai tahap perkembangan mentalnya. Hal ini sejalan dengan pemikiran yang dinyatakan oleh (Suyanto, 2005)mulanya bahasa dan pikiran anak berbeda, kemudian perlahan sesuai tahap perkembangan mentalnya, bahasa dan pikiran menyatu sehingga bahasa merupakan ungkapan dari pikiran. Disitulah bahasa ekspresif diciptakan oleh anak. Anak usia dini perlu menguasai keterampilan mengungkapkan bahasa ekspresif karena akan membantu anak dalam berinteraksi dengan orang lain (bersosialisasi), membuat bisa berpartisipasi dalam percakapan sehari-hari, juga membantu memecahkan masalah.

Kemampuan berbahasa anak tidak secara otomatis muncul dengan sendirinya,akan tetapi melalui stimulus yang mempengaruhi perkembangan berbahasa anak, dan diantara salah satu cara yang dilakukan untuk menstimulus perkembangan kemampuan mengungkapkan bahasa pada anak usia dini pada penelitian ini adalah dengan meneliti keefektifan literasi digital dalam pembelajaran pada anak usia 5-6 tahun di Taman Kanak-Kanak Aisyiyah cabang Ngageltersebut menemukan hasil yang signifikan. Kemampuan berbahasa anak usia dini yang dilakukan dengan stimulasi pembelajaran menyenangkan dan inovatif akan semakin bagus hasilnya dari pada dengan pembelajaran yang konvensional.

Taman Kanak-Kanak Aisyiyah cabang Ngagel ini termasuk salah satu upaya menstimulus perkembangan bahasa anak usia dini, dengan pembelajaran yang menyenangkan dan belajar seraya bermain dengan menggunakan digital sangat berpengaruh terhadap hasil yang diperoleh, dan hasil yang diperoleh dalam penelitian ini sangatsignifikan seperti yang dijelaskan diatas.

Dengan demikian maka pemanfaatan literasi digital dalam pembelajaran pada anak usia di Taman Kanak-Kanak Aisyiyah cabang Ngagel Surabaya sangatlah bermanfaat, terutama dalam mengembangkan pemahaman tehadap literasi digital anak yang sudah harus mulai dipikirkan dengan berkembangnya zaman teknologi yang semakin maju dengan pesatnya. 
P ISSN 2548-6284 E ISSN 2615-0360

Vol. 6 No. 1 Desember 2021

\section{SIMPULAN}

Keefektifan Literasi Digital Untuk Meningkatkan Kemampuan Berpikir Logis Dan Mengungkapkan Bahasa Pada Anak Usia Dini adalah sebagai berikut: 1). Keefektifan literasi digital dalam pembelajaran sangat berpengaruh dalam meningkatkan kemampuan anak usia dini dalam berpikir logis. Terdapat perbedaan nilai rata-rata kemampuan berpikir logis pada anak usia dini yakni kelompok eksperimen lebih besar pengaruhnya dari pada kelompok kontrol; dan 2). Keefektifan literasi digital dalam pembelajaran sangat berpengaruh dalam meningkatkan kemampuan mengungkapkan bahasa anak usia dini secara signifikan di Taman Kanak-Kanak Aisyiyah cabang Ngagel Surabaya. Uji-t satu jalur membuktikan bahwa terdapat perbedaan nilai rata-rata kemampuan mengungkapkan bahasa pada anak usia dini yakni kelompok eksperimen lebih besar pengaruhnya dari pada kelompok kontrol.

\section{DAFTAR PUSTAKA}

Baiti, N. (2020). Peran Orang Tua Dalam Meningkatkan Kemampuan Literasi Anak Di Masa Covid -19. Primearly, Vol. 3(No. 2). http://journal.iaisambas.ac.id/index.php/prymerl y/article/view/323

Clark, E, et al. (2018). Effectiveness of an Early Mobilization Protocol in a Trauma and Burns Intesive Care Unit. Critical Illness.

Darmawan, D. (2013). Metode Penelitian Kuantitatif. PT Remaja Rosdakarya.

Ellingson, K. (2016). Interactive Technology Use in Early Childhood Programs to Enhance Literacy Development \& Early Literacy Development for Children with Cochlear Implants. Semantic Scholar.

Haugland. (1992). The Effect of Computer Software on Preschool Children's Developmental Gains. Journal of Computing in Childhood Education.

Hurlock, E. B. (1997). Psikologi Perkembangan Suatu pendekatan rentang kehidupan, Edisi kelima,. Erlangga.

Kurnia. (2017). Literasi Digital Keluarga. Center For Digital Society (CFDS).

Muhammad Aspar, Imam Mujtaba, Mutiarani Mutiarani, A. Z. (2020). Efektivitas Implementasi Mendongeng Terhadap Literasi Bagi Anak Usia Sekolah Dasar. Prosiding Seminar Nasional Pengabdian Masyarakat LPPM UMJ. https://jurnal.umj.ac.id/index.php/semnaskat/arti cle/view/8062
Keeefktifan Literasi Digital ....

Umaiyah Habibah' Rachma Hasibuan² Sri Setyowati

Oladunjoye, O. K. (2013). iPad an Computer Devices in preschool: A Tool For Literacy Development Among Teachers and Chilren in Preschool. Department of Child and Youth Studie.

Rahmawati, Heni dan Tharmizi, A. (2018). Mobile Searching Objek Wisata Pekanbaru Menggunakan Location Base Service (LBS) Berbasis Android. Jurnal. Politeknik Caltex Riau.

Santrock. (2007). Perkembangan Anak Jilid 2 edisi ke 11. Erlangga/Glora Aksara Pratama.

Simanjuntak, M. D. R. (2019). Membangun Ketrampilan 4 C Siswa Dalam Menghadapi Revolusi Industri 4.0. Prosiding Seminar Nasional Fakultas Ilmu Sosial Universitas Negeri Medan. http://digilib.unimed.ac.id/37330/

Sufa, Feri Faila, Setiawan, M. H. Y. (2015). Implementasi Penjaminan Mutu pada Lembaga PAUD di Solo Raya . Jurnal Obsesi: Jurnal Pendidikan Anak Usia Dini.

Sugiyono. (2017). Metode Penelitian Kuantitatif. Alfa beta.

Suyanto. (2005). Konsep Dasar Anak Usia Dini. Departemen Pendidikan Nasional. 